\title{
Agrowaste bioconversion and microbial fortification have prospects for soil health, crop productivity, and eco-enterprising
}

\author{
Dhananjaya P. Singh ${ }^{1} \cdot$ Ratna Prabha ${ }^{1} \cdot$ Shukla Renu ${ }^{1} \cdot$ Pramod Kumar Sahu $^{1} \cdot$ Vivek Singh $^{1}$
}

Received: 11 May 2018 / Accepted: 14 January 2019 / Published online: 30 January 2019

(c) The Author(s) 2019

\begin{abstract}
Purpose Agricultural chemicals either used as nutrient inputs for soil fertility or pesticides are creating physicochemical and biological deterioration of the soils and disturbing the agro-ecosystems worldwide. Alarming concerns towards integrated agroecology demand for renewed interest in low-external input-based farming practices. These practices comprise strengthening of soil biological properties, recycling of inherent soil minerals and reuse of agricultural residual wastes.

Methods We described approaches for the bioconversion of agricultural residual wastes into value-added compost. The process involves conversion of residual waste into raw compost followed by its fortification with beneficial decomposer microorganisms to produce quality fortified compost product. Finally, incubation of fortified compost with single or consortia of beneficial microorganisms like $\mathrm{N}$-fixers, $\mathrm{P}$-solubilizers or K-mobilizers and biocontrol agents further enriches compost to produce bioorganic products.

Results Bioconversion of agricultural wastes into compost using potential decomposer microorganisms and fortification of decomposed organic matter with beneficial bacterial and fungal species is of immense importance. Additional enrichment of compost with botanicals, humic acid, amino acids, mineral nutrients, phytohormones etc. may also add value to the bioinput products.

Conclusion In an integrated way, on-farm production of raw compost using different agricultural residual wastes and its further fortification with bioorganic farm inputs can help farmers produce value-added compost products for direct application in the crop production. Adoption of microbial bioconversion technologies and their field applications may become eco-enterprising for the rural resource-poor farming communities for enhancing their livelihood along with improving farm productivity and soil health.
\end{abstract}

Keywords Microbial technology $\cdot$ Agricultural wastes $\cdot$ Bioconversion $\cdot$ Compost $\cdot$ Microbial inoculants $\cdot$ Bioorganic farm inputs

\section{Introduction}

Agricultural production has always been increasing pace due to the use of high-yield varieties which were input-intensive and demanded excessive chemical fertilizers and pesticides for supporting soil fertility and plant nutrition (Kibblewhite et al. 2008; Lorenz et al. 2013). Indiscriminate use of chemical inputs into the agricultural system has raised several problems concerned with the groundwater quality,

Dhananjaya P. Singh

dhananjaya.singh@icar.gov.in; dpsfarm@ rediffmail.com

1 ICAR-National Bureau of Agriculturally Important Microorganisms, Kushmaur, Maunath Bhanjan, Uttar Pradesh 275101, India soil agroecology and plant health (Power 2010). This has led to serious deleterious polluting impact on soil fertility, crop production, irrigation water, nutritional produce quality, and human health (Popp et al. 2013). Soils are continuously becoming low in organic carbon content and losing beneficial microbial communities. Agricultural chemicals have altered traditional cultivation practices and created physical, chemical, and biological deterioration of cultivable lands (Pretty and Bharucha 2014). Excessive chemical use has adversely influenced biodiversity of the soils, caused loss of nutritional ingredients and accumulation of non-desirable chemical intermediates in the food chain (Lal 2015). Other major problem associated with the chemical-dependent agricultural system is the increasing contamination of surface and groundwater due to residual pesticides, industrial 
wastes, heavy metals, and organic chemicals (Jaishankar et al. 2014; Khatri and Tyagi 2015).

Health of agricultural production system is at stake in the wake of shrinking land resources, increasing industrialization, expanding urbanization, excessive chemical usage and diminishing viable bioorganic inputs in the soils (Phalan et al. 2014). Agricultural sustainability is compromised due to the reducing biological wealth of farm resources. This needs to be suitably addressed to sustain long-term agricultural productivity to support food security and rural livelihood (Frison et al. 2011; Pradhan et al. 2015). There exists no simple or single way to understand and implicate such complex ecological, socioeconomic, and technological aspects of declining sustainability in agricultural systems (Pretty and Bharucha 2014). However, addressing connection between a balanced agro-ecosystem and sustainable crop productivity in a holistic manner could offer better solution to restore sustainability in agriculture systems.

Public concerns over adverse impacts of external chemical inputs on the quality of produce, farm soils, water and environment are rising (Bohlke 2002; Aktar et al. 2009; Mohanty et al. 2013; Hongsibsong et al. 2017). This has raised questions as to whether the present agricultural production system is able to provide quality food for all-over longer term (Hossard et al. 2014; Pradhan et al. 2015). Therefore, many countries are now taking initiatives to reduce the use of fertilizers and pesticides in the food crop production system (FAO 2017). Green Revolution witnessed high pace of crop productivity in the past few decades. However, now this has left with emerging associated risks of dependence on high external inputs, disturbance of agroecology and resurgence of pests and diseases (Pingali 2014; Godfray and Garnett 2014). Such threatening concerns have generated renewed interest in the alternative ways of farming practices that are based on recycling and reuse of farm wastes as bioorganic inputs to enhance soil productivity (Schröder et al. 2018). This has also provoked current thinking on intensified promotion of soil biodiversity and biogeochemical processes that enhance soil carbon and microbial communities having specific functional traits (Gattinger et al. 2012; Lori et al. 2017). Results from long-term experimental data generated on nitrogen fertilization strategies in Italy for limiting environmental risk from excessive $\mathrm{N}$-application and animal farming created Nitrates Directives application scheme for more relaxed application of manure-N. Studies reflected that application of composted materials with bacterial biofertilizers improved soil microbial community structure and diversity in degraded soils from croplands (Zhen et al. 2014). Similar practices can balance bioorganic and microbiological equilibrium of the soils in the ways that simultaneously favor production and protection of food crops along with the soil fertility status.
Crop production strategies based on low external input farming practices that nurtured ecological dynamics have potentials of minimizing chemical fertilizers, inorganic inputs and pesticides. This has reliably led to reducing the cost of production, producing high-quality nutritionally valuable and sellable crop produce, ensuring ecological safety and rural livelihood and most importantly, holistic human health (Kesavan and Swaminathan 2008). In such a farming system, crop yield is maintained through greater emphasis on cultural practices, use of biological inputs, integration of pest/disease management practices and managed utilization of on-farm agricultural resources (Gliessman and Rosemeyer 2010; Branca et al. 2011; Osteen et al. 2012). Making the soils rich in organic carbon support diverse microbial inhabitants that in turn promote soil functions (Gougoulias et al. 2014; Trivedi et al. 2016). Global land distribution and soil quality are compromised due to high pressure to produce more crops, changing pattern in global food consumption, insufficient adoption of soil management practices, urbanization, and industrialization and life style of the population (Blum 2013). The role of organic carbon richness in the soils in terms of its functional benefits is obvious (Clara et al. 2017). Usually low-carbon soils fail to support diverse microbial attributes that naturally drive ecosystem functions independently (Louis et al. 2016). Therefore, there is a need to implicate enhanced availability of organic matter in the soils for sustainable improvement in crop productivity and tolerance against biotic and abiotic stresses (Zhang et al. 2016). Site-specific organic carbon content in the top-soils is a major prerequisite for sustainable soil functions indicating a good soil quality and agronomic value (Seremesic et al. 2011). Decline in soil organic matter due to insufficient addition of organic manures, low crop rotation and management practices (like tillage, fertilization) and on-farm crop residue burning is widely reported (Bhan and Behera 2014; Godde et al. 2016). The organic content of the soils can be improved by increasing organic matter gain of the soils through the addition of decomposed materials or by reducing organic matter losses through released respiring carbon by microorganisms (Carter 2002).

One of the potential sources of organic carbon return to the soils is the crop residue produced during the cropping season and post harvest. These residues usually go waste and create environmental sanitation issues. However, if incorporated in the soils it can increase crop yield (Han et al. 2017). Loss of organic carbon from the soil reduces crop productivity worldwide. Therefore, locally feasible practices are needed to support farmers to help regain soil organic matter (Wei et al. 2015). Farmers usually lack knowledge on the importance of microbial resources in the above-ground and below-ground soils and benefits of their on-farm implications. They also lack information on biological management of farms using microbial technologies, potentialities of 
managed integration of on-farm resources and conversion of agro-wastes into organic farm inputs to enhance soil capabilities (Han et al. 2017). These issues, if accepted, worked out and adapted by the resource-poor farmers can help in minimizing dependency on external chemicals and fertilizers, reducing cost of crop production and improving ecosystem services in the soils. Therefore, the agricultural residue decomposition technology using microbial interventions and fortification of the compost with beneficial microorganisms has immense scope.

We reviewed significance of microbe-mediated agrowaste bioconversion practices and their reuse for strengthening soils. We described how fortification and bioaugmentation of the raw decomposed products using specific microbial inoculants that act as decomposers, plant growth promoters and/or bioagents can help farmers obtain functionally potential bioorganic farm inputs? The usefulness of such technologies in producing different crops has also been summarized with specific examples from the field-scale applications.

\section{Microorganisms are the key to agrowaste bioconversion}

The ways in which microorganisms have been used to advance human and animal health, food processing, food safety and quality, environmental protection, crop production, and agricultural biotechnology has made them alternatives for high-input farming practices. Lignocellulose that consists of cellulose, hemicellulose and lignin represents major structural component of agricultural crop residues (Pothiraj et al. 2006). Due to extensive agricultural activities, huge amounts of agricultural residues contribute significantly to the yearly global yield of lignocellulose (Loow et al. 2015). Various agricultural residues that contain up to 20-30\% lignin-hemicellulose-have potential biotechnological values because of their bioconversion and/or fermentation to yield industrially important constituents including biofuels (Sorek et al. 2014). However, due to the recalcitrant nature of the lignin, which has resistance against microbial attack (Loow et al. 2017a), cost-efficient methods to reutilize the lignocellulose components within the biomass effectively have remained challenging (Loow et al. 2017b). Much of the lignocellulose wastes create environmental pollution problems if remained in the farm either as biomass or burnt upon. Huge amount of lignocellulosic wastes if converted to the value-added products using enzymes such as cellulases, glucanases, hemicellulases, glycosidase hydrolases, polysaccharide lyases and carbohydrate esterases or with the help of microbes (Himmel et al. 2010) can yield chemicals, fuel, textile, paper, and agricultural inputs (Pothiraj et al. 2006).

Bioconversion, more specifically composting of agricultural residues refers to step-wise biodecomposition procedures carried out due to the intervention of different microbial communities under aerobic conditions (Pan et al. 2012). The end product of the aerobic composting yields stabilized organic product, which is beneficial for plant growth and development. Efforts on microbial intervention for better decomposition gained strength from the identification and characterization of such microbial communities from the agricultural soils, composts, vermicompost and humusrich sites, that prominently catalyzed biodegradation and decomposition (Eida et al. 2012). Scaling-up of bioconversion processes and large-scale production technologies using microbial inoculants have resulted in producing mass-scale composted material that may be bioaugmented with beneficial microorganisms or fortified with organic inputs, bioinoculants, and vermicompost (Singh and Sharma 2002; Nair and Okamitsu 2012; Malusá et al. 2012). Composted products were reported to act as soil conditioners in low-cost crop production practices for resource-poor farming communities (Gajalakshmi and Abbasi 2008).

The uniqueness of microorganisms and their functions have made them potential candidates for decomposing agricultural residues into valuable products (Kumar and Sai Gopal 2015). Microbial communities have emerged to influence litter decomposability and size of nutrient pool in the soils. They primarily immobilize mineralized nutrients into microbial biomass and release nutrients from microbial pool after decomposition (Sahu et al. 2018). This phenomenon has major impact on the bioavailability of nutrients to the plants (Miki et al. 2010). It further regulates cycling of nutrients into the soils. Various microorganisms possess enzyme activities directly linked to the decomposition of organic materials which under improved composting conditions yield better compost products (Eida et al. 2012). There have been several reports on the isolation and trait characterization of microbial communities that can perform functionally better in combination with the existing rhizosphere bacteria, beneficial mycorrhizal fungi and biological control agents (Boulter et al. 2002; Anastasi et al. 2005; Vishan et al. 2017). The decomposed organic matter when used in the soils makes native beneficial microorganisms more effective due to their rich carbon content (Meena et al. 2014; Rashid et al. 2016). Vermicompost, a composted product produced by the intervention of earthworm Eisenia fetida is also known to enhance native soil microbial diversity and promote plant growth (Lim et al. 2015). Bacterial diversity from vermicompost exhibiting plant growth promoting traits has been investigated (Singh and Sharma 2002; Pathma and Sakthivel 2012). Co-inoculation of beneficial bacterial and fungal organisms like species of Rhizobium, Azotobacter, Azospirillum, Pseudomonas, Bacillus, Burkholderia cepacia, Candida oleophila, Coniothyrium minitans, C. sclerotiorum, Aspergillus niger, Fusarium oxysporum (nonpathogenic), Gliocladium spp., Phlebia gigantean, Pythium 
oligandrum, Streptomyces griseoviridis and Trichoderma spp. with organic matter-rich compost can add to the soil health. Such practices are known to improve crop productivity through diverse mechanisms through nutrient acquisition, mineralization, carbon addition and phytohormone production (Rashid et al. 2016; Meena et al. 2017). The species of Rhizobium, Azotobacter, Azospirillum, and phosphate solubilizing microorganisms that are currently being used as commercial formulations of biofertilizers, when added in combination with the compost can also provide major support to agriculture (Reddy and Saravanan 2013; Sharma et al. 2013). Use of farm yard manure (FYM), vermicompost and other humus-based organic farm inputs also support agricultural production. Overall, organic and microbially fortified farm-supplement constituents as termed by the names biofertilizers, biopesticides, microbial inoculants, soil conditioners if used in an integrated manner can make soils more live, healthy, and viable for improved crop production (Parnell et al. 2016).

Microbial bioconversion of agricultural waste, household waste or other natural products like leaf litter and nondecomposed matter into compost products was developed in the past several years. Various microorganisms were reported as fast decomposers, biodegraders, and bioconverters of non-useful products (Gautam et al. 2012). Fungal communities develop fast in the arable soils in straw residue degradation conditions (Ma et al. 2013). Rapid changes have also been observed in primary decomposer fungal communities suggesting that litter decomposition is a highly complex process mediated by diverse taxa (Voříšková and Baldrian 2013). Bacterial succession on plant residual biomass decomposition also exhibits specific pattern of bacteria and fungus communities. Results on bacterial succession suggested early-stage (2-4 months), mid-stage (6-8 months) and later-stage (10-24 months) prominent changes in decomposer communities (Tláskal et al. 2016).

The role of microorganisms as bioconversion agents is important due to their fast ability to convert cellulosic and lignocellulosic wastes into organic materials (de Souza 2013). Mature compost in combination with microbial consortia more prominently helps bioremediation of environmental pollutants (petroleum hydrocarbons) (Gomez and Sartaj 2014). It also improves microbial interaction with root rhizosphere to promote plant growth and develop top-soil structure (Sinha et al. 2009; Abhilash et al. 2016; Marcela et al. 2017). Composting process usually involves three phases in which diverse microbial organisms like bacteria, actinomycetes and fungi act on the lignocellulosic components of the residue biomass. This converts waste into humus under mesophilic (Streptomyces rectus) and thermophilic (Actinobifida chromogena, Thermomonospora fusca, Microbispora bispora) conditions (Pan et al. 2012; Zeng et al. 2016). The first phase initiates with the rise in temperature and reduces substrate by degradation action of mesophiles (Zeng et al. 2016). This is followed by the increase in the temperature up to $70{ }^{\circ} \mathrm{C}$ due to the abundant activities of thermophilic microorganisms (Schloss et al. 2003). Benefits of the thermophilic phase lie in terms of the loss of pathogenic bacteria and fungi which are degraded due to high temperature. Afterwards, the compost pile temperature returns to normal stage (Novinscak et al. 2008). The process of decomposition of crop residues involves differentially variable conditions $(\mathrm{pH}$, temperature, moisture, nutrient availability) for the microbial communities involved during the period of degradation. Certain organisms like Coprinus species belonging to Basidiomycota grow well in alkaline conditions while other fungi, e.g., Trichoderma, Mucor, Nocardia, and Phanerochaete chrysosporium need optimum $\mathrm{pH}$ (5.5-8.0) for attaining high population that could help rapid biodegradation (Varma et al. 2017). The decomposition ability of the microbial communities is largely influenced by the conditions of the residual waste products being decomposed like $\mathrm{pH}(<7.0)$, moisture content $(\sim 60 \%)$, volatile ammonia emission $(30-70 \%)$, temperature $\left(30-60{ }^{\circ} \mathrm{C}\right)$ and different organic mixtures (polysaccharides, cellulose, hemicellulose, amino acids, and fatty acids) (Urbanová et al. 2015). Conventional processes were reported in the past but rapid composting using microbial consortia is more advanced and advantageous concept due to the ease of controlled environment, identified ingredients for fast degradation and timely composting (Chen et al. 2016; Patchaye et al. 2018).

The enteric fermentation of the ruminants from the livestock, especially of the cattle used at large scale in agricultural practices leads to the production of green house gases (GHGs). One such gas methane $\left(\mathrm{CH}_{4}\right)$ contributes to almost $1 / 3$ rd of the total emissions of GHGs from agricultural sector (https://www.epa.gov/ghgemissions/sources-greenhouse -gas-emissions\#agriculture). The other gaseous emission in agricultural sector that largely contributes to GHGs in the environment includes nitrous oxide and carbon dioxide, the mitigation of which needs specific technologies associated to irrigation type and nitrogen use status (Sanz-Cobena et al. 2017). Improper manure management, burning crop residues in the fields, application of synthetic nitrogenous fertilizers and high nitrogen crops are the major factors that contribute to the GHGs in the environment (http://www.ipcc.ch/ipccr eports/tar/wg3/index.php?idp=115). Agricultural residues or animal wastes, when left in the fields for months have possibilities of uncontrolled decomposition by undesirable bacteria or fungi and therefore, are liable to produce more amount of GHGs (Patra and Babu 2017). Associated with this, there always remains risk of polluting air and water with nitrogen and microbial pathogens (Venglovsky et al. 2009). For this reason, safety concerns for the use of animal manures in the soils by spreading onto the land is challenging and needs various treatment methods for the deactivation 
of pathogenic microbial species (Martens and Böhm 2009). However, the controlled composting such as conversion of pig slurry into pellets help farmers improve soil properties due to reduction in ammonia volatilization and mitigate GHG emissions (Pampuro et al. 2017a, b). Microbe-mediated controlled composting yields composted products from livestock wastes also in a time-lined manner with the use of known microbial degraders and specific ingredients. This becomes helpful in obtaining decomposed products of specific $\mathrm{C}: \mathrm{N}$ ratio having beneficial microbial communities for direct field utilization ( $\mathrm{Ng}$ et al. 2016).

\section{Technological aspects of microbial bioconversion of agricultural wastes}

One of the major identified reasons for declining agriculture sustainability is poor soil condition due to reduced application of organic matter into the farms and non-conservational practices that majorly disturb top soils (Kibblewhite et al. 2008; Hobbs et al. 2008). Huge volume of agricultural wastes in farmer's fields has economic and environmental benefits as suggested by the studies on pyrolysis and biochar of rice straw, corn stover, orchard, and animal wastes (Kung et al. 2015). Crop wastes blended with the cow dung for biogas production after anaerobic digestion using anaerobic bacteria (acidogenic and acetogenic bacteria) generate electricity through potential technologies (Muthu et al. 2017). The product of anaerobic digestion after waste treatment or the digestate remains can add value through decomposition. Prominent microbial community dynamics was observed when the anaerobic digestate from the municipal food residues, and green and kitchen wastes were composted under natural composting conditions (Franke-Whittle et al. 2014). Understanding on microbial dynamics during different phases of composting helped better control of bio-oxidative processes followed by stabilization and maturation phases that use specific technology in static reactor of high capacity (up to $600 \mathrm{~L}$ or more) (Villar et al. 2016). Studies have opened new avenues for better utilization of anaerobic digestate after improved composting using beneficial microorganisms, the products of which could be directly utilized in the farms for improving soil organic content (Zeng et al. 2016). Such composts proved to be good alternatives of farmyard manures for field application.

Composting technologies are farmer-friendly, reproducible, easy to adopt and yield productive inputs for the farms to sustain agricultural productivity beside generating biogas for bioenergy (Achinas et al. 2017). Agricultural residues have remained tremendous sources of bioenergy worldwide. Crop dry matter and oil-rich residual biomass have attained the attention due to their huge yearly quantitative volume of $\sim 11.33$ million tons that could be converted to
3.84 giga-liters (GI) of bioethanol, 1.07 GI biobutanol, 3.15 billion Cu-Meter (BCM) biogas and 1.0 BCM of biohydrogen (Karimi and Yaghmaei 2016). Under methanogenic condition, hydrogen, carbon dioxide, and methane are generated due to the action of degrading enzymes on residual crop biomass. Another important aspect of crop residual resource management lies with the characterization and thermal conditioning of bio-oils into fuel production (Bertero et al. 2012). These technologies, based on the microbial role in waste bioconversion have also been developed for the production of ethanol, biofuels, platform chemicals, and biorefinary products (Mielenz 2001; Prassad et al. 2007; Weber et al. 2010; Msangi 2012). In India, nearly 700 million tons of organic residual wastes are generated annually (Nagavallemma et al. 2004). One of the most prominent ways of the safe disposal of the majority of waste is composting which is an environmentally sound bioprocess of converting organic residual wastes into valuable products for farms (Pan et al. 2012). Besides, if scaled up and industrialized, these products can also meet alternative fuel needs through sustainable waste management practices (Weiland et al. 2009). Various microorganisms, their potential constituents that help in fast decomposition, biodegradation and bioconversion of crop residues and other valuable products are listed in Table 1.

Microorganisms are the major key players in maintaining nutrient flow from residues to the farm soils (Erickson et al. 2009). Plant materials, especially the crop residues are rich in lignocellulosic biomass but have crystalline structures embedded with silica, lignin, suberin, and other polymeric constituents that hinder the process of smooth microbial degradation for composting (Huber and Praznik 2004). Therefore, pretreatment of lignocellulosic biomass with the help of acid, alkali, steam, urea, and hydrolytic enzymes is recommended for substantial breakdown of hard constituents to smoothen the process of composting (Mosier et al. 2005; Table 1). Lignolytic enzymes produced by some potential microbial isolates can also be a source of rapid biodegradation module for large-scale and effective lignin degradation (Table 1) (Fenga et al. 2011). The role of gut microorganisms like Coptotermes formosanus isolated from termites is also important in changing physicochemical properties of the crop residues. Cellulose and lignins can be made readily available for the existing microbial communities for degradation (Harazano et al. 2003). Potential microorganisms with impressive enzymatic capabilities for fast degradation of recalcitrant lignin are discussed (Table 1) (Perez et al. 2014; Varma et al. 2017). Since these organic compounds possess complex interlinked fractions, their biomass valorization is tough and highly resistant to hydrolysis and solubilization (Kumar and Sharma 2017). Therefore, instead of a single process for pretreatment, multiple physical, chemical, and biological steps are required in an integrated way to minimize undesirable inhibitors (Masran 
Table 1 Various bacteria and fungi have been isolated, identified, and their products, especially enzymes were used for enhanced decomposition and degradation of agricultural residues into compost

\begin{tabular}{|c|c|c|c|c|}
\hline S. no. & Microorganisms & Biodegradation activity & Nature of organic matter & References \\
\hline \multicolumn{5}{|l|}{ Fungi } \\
\hline 1. & Pleurotus sajor-caju & $\begin{array}{l}\text { Exocellular lignocellulose } \\
\text { degradation }\end{array}$ & Multiple matters & Singh (2000) \\
\hline 2. & Pleurotus flabellatus & $\begin{array}{l}\text { Exocellular lignocellulose } \\
\text { degradation }\end{array}$ & Rice straw, sisal leaves & Mshandete and Cuff (2008) \\
\hline 3. & Pleurotus eryngii & $\begin{array}{l}\text { Lignocellulose degradation, lac- } \\
\text { case enzyme activity (degrada- } \\
\text { tion of phenolics) }\end{array}$ & Agricultural wastes & Yildirim et al. (2015) \\
\hline 4. & Aspergillus niger & Cellulase, xyalanase production & $\begin{array}{l}\text { Pre-decomposition of organic } \\
\text { matter, sugarcane bagasse }\end{array}$ & $\begin{array}{l}\text { Singh and Sharma (2002); } \\
\text { Romero et al. (2007) }\end{array}$ \\
\hline 5. & Trichoderma harzianum & $\begin{array}{l}\text { Hemicellulose degradation } \\
\text { (hemicellulase production) }\end{array}$ & $\begin{array}{l}\text { Pre-decomposition of organic } \\
\text { matter }\end{array}$ & $\begin{array}{l}\text { Singh and Sharma (2002); } \\
\text { Jorgensen et al. (2003) }\end{array}$ \\
\hline 6. & Trichoderma reesei & $\begin{array}{l}\text { Cellulase and hemicellulase } \\
\text { production }\end{array}$ & $\begin{array}{l}\text { Commercial production of } \\
\text { enzyme for degradation }\end{array}$ & Nieves et al. (1998) \\
\hline 7. & Penicillium brasilianum & $\begin{array}{l}\text { Cellulases and xylanases produc- } \\
\text { tion }\end{array}$ & $\begin{array}{l}\text { Commercial production of } \\
\text { enzyme for degradation }\end{array}$ & Jorgensen et al. (2003) \\
\hline 8. & Phanerochaete chrysosporium & $\begin{array}{l}\text { Lignin peroxydases, glyoxal oxi- } \\
\text { dase, manganese peroxydases } \\
\text { (lignin degradation enzymes) }\end{array}$ & $\begin{array}{l}\text { Lignin-containing biomass like } \\
\text { wood shavings, agro wastes }\end{array}$ & $\begin{array}{l}\text { Martinez (2002), Kersten and } \\
\text { Cullen (2007) and Zhang } \\
\text { et al. (2013) }\end{array}$ \\
\hline 9. & Xylaria hypoxylon & $\begin{array}{l}\text { Xylanase, laccase, glucosidase, } \\
\text { esterase }\end{array}$ & Woody materials & Liers et al. (2006) \\
\hline 10. & Pycnoporus cinnabarinus & $\begin{array}{l}\text { Lignin peroxidases, manganese } \\
\text { peroxidases, laccase }\end{array}$ & Woody materials & Alves et al. (2004) \\
\hline 11. & Trametes versicolor & Laccase & $\begin{array}{l}\text { Agro wastes and woody sub- } \\
\text { strates }\end{array}$ & Cabuk et al. (2006) \\
\hline 12. & Aspergillus awamori & Cellulases & Agro wastes & $\begin{array}{l}\text { Gaind and Nain (2007) and } \\
\text { Pleissner et al. (2013) }\end{array}$ \\
\hline 13. & Paecilomyces marquandii & Keratinase & Poultry waste (feather waste) & Veselá and Friedrich (2009) \\
\hline 14. & Phanerochaete chrysosporium & $\begin{array}{l}\text { Increases the humification } \\
\text { degree of humic acid }\end{array}$ & Agro waste & Huang et al. (2009) \\
\hline \multicolumn{5}{|c|}{ Bacteria and actinomycetes } \\
\hline 15. & Bacillus sp. & Lignin degradation & Degradation of pulp paper waste & Chandra et al. (2007) \\
\hline 16. & Paenibacillus sp. & Lignin degradation & Degradation of pulp paper waste & Chandra et al. (2007) \\
\hline 17. & Aneurinibacillus aneurinilyticus & Lignin degradation & Degradation of pulp paper waste & Raj et al. (2007) \\
\hline 18. & Pseudomonas putida & $\begin{array}{l}\text { Manganese peroxydases and } \\
\text { laccase }\end{array}$ & Agro waste & Ahmad et al. (2010) \\
\hline 19. & Pseudomonas aeruginosa & $\begin{array}{l}\text { Manganese peroxidases, lipid } \\
\text { peroxidase and laccase }\end{array}$ & Agro waste & Bholay et al. (2012) \\
\hline 20. & Serratia marcescens & $\begin{array}{l}\text { Manganese peroxidases, lipid } \\
\text { peroxidase and laccase }\end{array}$ & Agro waste & Chandra et al. (2012) \\
\hline 21. & Citrobacter freundii & $\begin{array}{l}\text { Manganese peroxidases, lignin } \\
\text { degradation }\end{array}$ & Agro waste, saw dust & Ali et al. (2017) \\
\hline 22. & Streptomyces spp. & $\begin{array}{l}\text { Cellulases, xylosidase, acety- } \\
\text { lesterase, xylanases }\end{array}$ & Agro waste & Benimelia et al. (2007) \\
\hline 23. & $\begin{array}{l}\text { Bacillus licheniformis and a } \\
\text { Streptomyces sp. }\end{array}$ & $\begin{array}{l}\text { Keratin degradation by Kerati- } \\
\text { nases }\end{array}$ & Poultry waste & Ichida et al. (2001) \\
\hline 24. & $\begin{array}{l}\text { Mono and co-cultures of } B \text {. } \\
\text { subtilis and } P \text {. ostreatus }\end{array}$ & Cellulase & $\begin{array}{l}\text { Apple and plum wastes mixed } \\
\text { with cereal wastes. }\end{array}$ & Petre et al. (2014) \\
\hline 25. & Geobacillus strains & Boost the total bacterial count & Vegetable waste & Pal et al. (2010) \\
\hline 26. & $\begin{array}{l}\text { Stenotrophomonas maltophilia, } \\
\text { Scedosporium apiospermium }\end{array}$ & Biodegradation of asphaltens & $\begin{array}{l}\text { Asphaltens from Prestige oil } \\
\text { spill }\end{array}$ & Martín-Gil et al. (2008) \\
\hline 27. & $\begin{array}{l}\text { Bacillus cereus, Bacillus mega- } \\
\text { terium }\end{array}$ & $\begin{array}{l}\text { Breakdown of cellulose and } \\
\text { hemicelluloses }\end{array}$ & Organic substrate & Ribeiro et al. (2017) \\
\hline
\end{tabular}


et al. 2016; Shrestha et al. 2017). Maintenance of proper $\mathrm{pH}$, temperature, air (oxygen) and moisture conditions and softening of the surface layer of residual biomass with the help of surfactant or urea is helpful. Likewise, fungal treatments in which fungi and actinomycetes directly colonize with the residues or enzymatic treatments using lignolytic enzymes help improving biodelignification process (Ilyin et al. 2004; Moreno et al. 2015). It further needs exposure of suitable mesophilic and thermophilic conditions that may include combined organic and inorganic complexes like $\mathrm{CuSO}_{4}$-gallic acid supplement for aggravating high functional bioconversion activities (Mishra and Jana 2017).

The bioconversion process can be fastened with the use of such functionally characterized microbial inoculants that possess high enzymatic activities for lignocellulosic degradation (Choudhary et al. 2016). Industrial composting for mushroom production is an established biological procedure to produce Agaricus bisporus (Jurak et al. 2014). Mushrooms are among the most fascinating fungal organisms to be used as pretreatment degraders of the lignocellulose constituents of crop residues and perform improved enzymatic release of monosaccharides for biofuels. It also helps to convert residual biomass into valuable protein-rich edible fruits of high nutritional importance (Jurak et al. 2015). Compost preparation for mushroom production involves microorganisms that decompose natural lignocellulose into simple mineral components, on which mushroom mycelial mass grows and produces fruiting bodies (Mouthier et al. 2017). Therefore, besides obtaining high-value protein-rich functional food product from the bioconversion of crop residues by mushroom fungi (Chang 2008), farmers can also get value-added compost for their farms to enhance crop production and soil fertility. Fortification of raw compost with plant growth-promoting bacteria and biocontrol agents like Trichoderma harzianum potentially enhance suppressiveness of soil-borne diseases and efficacy of compost microbiota against pathogenic diseases (Pugliese et al. 2011; Ros et al. 2017). Mushroom production is of high economic significance in many parts of the world (Marshall and Nair 2009; Zhang et al. 2014) and compost fortified with beneficial microorganisms also has potentials of enterprising (Awad and Khaled 2012; Sarkar and Chourasia 2017).

Direct composting of agricultural crop residues using large windrows allows thermophilic conditions to convert high volume of lignocellulosic wastes into stable compost with specific ingredients of definite $\mathrm{C}: \mathrm{N}$ ratio (Vigneswaran et al. 2016). The whole process is biochemically sound and mediated by microbial metabolic activities that produce heat, water, $\mathrm{CO}_{2}$ and results in mineralization, transformation, and humification (Shilev et al. 2007). The technology is cheaper and sustainable in terms of its requirements for ingredients, manpower, energy, water, time, resource integration, and reproducibility. As far as the agricultural benefits are concerned, in controlled and defined conditions, the process can yield organic matter disinfected by high temperature. It is also a mineral-rich nutritional substance that improves structural components of the soil by degrading large complex molecules into simple ones for soil fertility (Sonesson et al. 2000). After production of goodquality compost using windrows, biofortification of the raw product can be done with the use of beneficial microbial inoculants (plant growth-promoting bacteria, mycorrhiza, and biocontrol fungi) (Muttalib et al. 2016). Enrichment of raw compost material with organic inputs like humic acid, amino acids, phytohormones, mineral nutrients (zinc, iron, boron), phytonutrients, botanicals and vermicompost can further add value to the products that can help in organic farming (Mohler and Johnson 2009).

Large-scale livestock production systems are the source of huge amount of agricultural residual biomass of manures and slurries that can be applied to the land for fertility improvement (Bernal et al. 2009). Pig slurries and poultry manures have remained a common source of composting ingredient (Pampuro et al. 2016). Co-composting of wastes from winery distilleries with animal and poultry manure under static pile composting system was assessed on different parameters such as $\mathrm{pH}$, electrical conductivity (EC), organic matter, soluble carbon, polyphenolics content, humification characteristics, and plant germination index (Bustamante et al. 2008). Agricultural food wastes are also attractive composting materials for their conversion into decomposed manures to be used for producing high-value crops (Rubio et al. 2013). It was largely considered that composting processes that ensure nutrient-rich conditions, appropriate carbon rating, organic matter humification and adequate bulking for reducing $\mathrm{N}$-losses are required to overcome production cost (Bernal et al. 2009). Results confirm that composting helped in detoxification and degradation of phytotoxic compounds in the residual matter and therefore, offers a favorable way to recycle wastes into value-added products (Pampuro et al. 2016).

\section{Potential benefits of microbe-mediated compost as farm inputs}

The role of microorganisms as bioconversion agents and their ability to convert cellulosic and lignocellulosic wastes into organic materials, bioremediate environmental pollutants and interact with root rhizosphere to promote plant growth and soil structure were defined (Sánchez 2009; Huang et al. 2010). They are inevitable for the natural resource management in the farmers' fields. Controlled composting guided by microbial interventions dependent on defined microbiological processes to decompose agricultural residues properly and timely and produce high-value 
low-cost bioorganic farm inputs (Ahmad et al. 2007; Singh and Nain 2015; Singh and Prabha 2017; Sudharmaidevi et al. 2017). This is how rapid composting processes can help farmers in timely production of compost and fortified bioorganic farm inputs of desired quality for organic farming needs and high-value commercial crops like vegetables, fruits, flowers, and organic crops (Hoornweg et al. 2000; Seyedbagheri 2010). If farmers need biopesticide-rich compost material for the control of soil-, seed- or seedlingborne fungal pathogens in the field, they can biofortify the raw compost with bioagents (Siddiqui et al. 2008; $\mathrm{Ng}$ et al. 2016). Similarly, consortium of microorganisms fixing nitrogen, solubilizing phosphorus and zinc and mobilizing potassium can be utilized to fortify raw compost material for desired quality under suitable enriching conditions of temperature and moisture. This can yield potential bioorganic inputs enriched with $\mathrm{N}, \mathrm{P}, \mathrm{K}$ and $\mathrm{Zn}$-harvesting and recycling microbial population (Pugliese et al. 2011; Baig et al. 2012; Kamran et al. 2017; Pallavi et al. 2017). The whole process remains at the ease of the farmer's need, expertise, indigenous resource availability, local conditions, and existing human resources.

Microbe-mediated activities that favor efficient composting processes, technological aspects of agrowaste bioconversion, microorganisms involved, benefits of microbial fortified and enriched compost and options for adopting such microbial technologies as models of eco-enterprising are discussed. All these steps are simple and easily adaptable by the farming communities. Also, the ingredient resources are usually available with the farmers at their homes. The method is helpful in reintroducing organic matter to the soils along with the beneficial microorganisms that help soils to improve nutrient status for plant growth and development. Adoption of such practices in farmers can not only increase rural sanitation at ground level and support cleanliness drives of the governments worldwide, but can improve soil fertility status also. The method yields value-added low-cost farm inputs from the agricultural farm residues that would otherwise go waste. When burnt at farmer's fields, it creates obnoxious green house gases (GHGs), fog, and smog. These products are enriched with microbial consortia of plant growth promoting and biological control microorganisms. These organically rich bio-farm inputs have functional benefits of microorganisms.

\section{Agrowaste bioconversion as eco-enterprising model}

Proper utilization of agricultural crop residues can benefit farms and farming communities. When developed in the form of an eco-enterprising model, microbe-based bioconversion of crop residues can be of immense help of rural communities to generate rural livelihood through the products of commercial utility (Naresh 2013). Mushroom production in rural parts of many countries has gained the shape of eco-business because of prominent reasons. Firstly, it has rooted in locally available farm residual resources, which usually go waste. Secondly, it can be performed with practical skills, which may be inculcated in the farming communities through learn-by-doing methods and thirdly, it can yield high-value food for family use and/or additional income, if commercialized (Marshall and Nair 2009; Valverde et al. 2015). Looking into the potential benefits of mushroom production in terms of high-value food, waste utilization and spent management (as enzymes, proteins or microbe-fortified compost) (Phan and Sabaratnam 2012; Kumar et al. 2014), prospective eco-enterprising model for rural farming communities or agro-industries can be developed (Celik and Peker 2009). A workable and integrated eco-enterprising model of agrowaste bioconversion and fortification with the help of beneficial microorganisms is presented (Fig. 1). The model can be promoted into the farming communities to attract resource-poor farmers towards various biological, technological and commercial aspects of on-farm bioconversion agro-waste management. This may also be helpful in strengthening the rural economy at a developmental stage by introducing diversified business and income generation opportunities for the rural people (Singh et al. 2010).

It has been demonstrated that the bioconversion of crop residues like straw, husk, corn cobs, bagasse and vegetative materials coming from regularly grown field crops can be converted into raw compost using windrows at farmer's fields (Singh and Prabha 2017). The raw compost was further fortified with the plant growth promoting microorganisms or biocontrol agents like Trichoderma and Pseudomonas to scale up the efficiency of microbial formulations (Galitskaya et al. 2016). The strength of raw compost can also be improved by the addition of poultry wastes and degradation with the help of microbial enzymes (Brandelli et al. 2015). In the very simple steps, bioconversion processes of agricultural wastes can be disseminated among rural population for adoption of such microbe-based models of biobusiness. The impact of pelletizing pressure for developing solid state compost from different composting materials like pig solid fraction, bulking agents, e.g., biochar and wood chips, swine manure solid fractions and organic co-formulates was assessed for standardizing physical and mechanical properties of the composted material (Romano et al. 2014; Pampuro et al. 2017a, b). These studies resulted in developing farmer-friendly and easily adaptable composted products with quality standards for commercialization and enterprising. These models are supposed to be developed for introducing multi-enterprising support for smart agriculture system (Pramanik et al. 2013). 
Fig. 1 Agrowaste bioconversion model based on crop residues as primary composting resource in three steps (1) agricultural waste (wheat, paddy straw, and crop leaves) is converted into raw compost in 30-35 days using different kinds of ingredients (C:N ratio 17:1); (2) raw compost is further decomposed in next 30 days using decomposer microbial consortia to produce bioorganic farm inputs with C:N ratio of 30:1 and (3) fortification with beneficial microorganisms like nitrogen fixers, phosphate solubilizers, biocontrol agent(s), humic acid, micronutrients for 15 days to obtain microbe-enriched products for direct farm applications

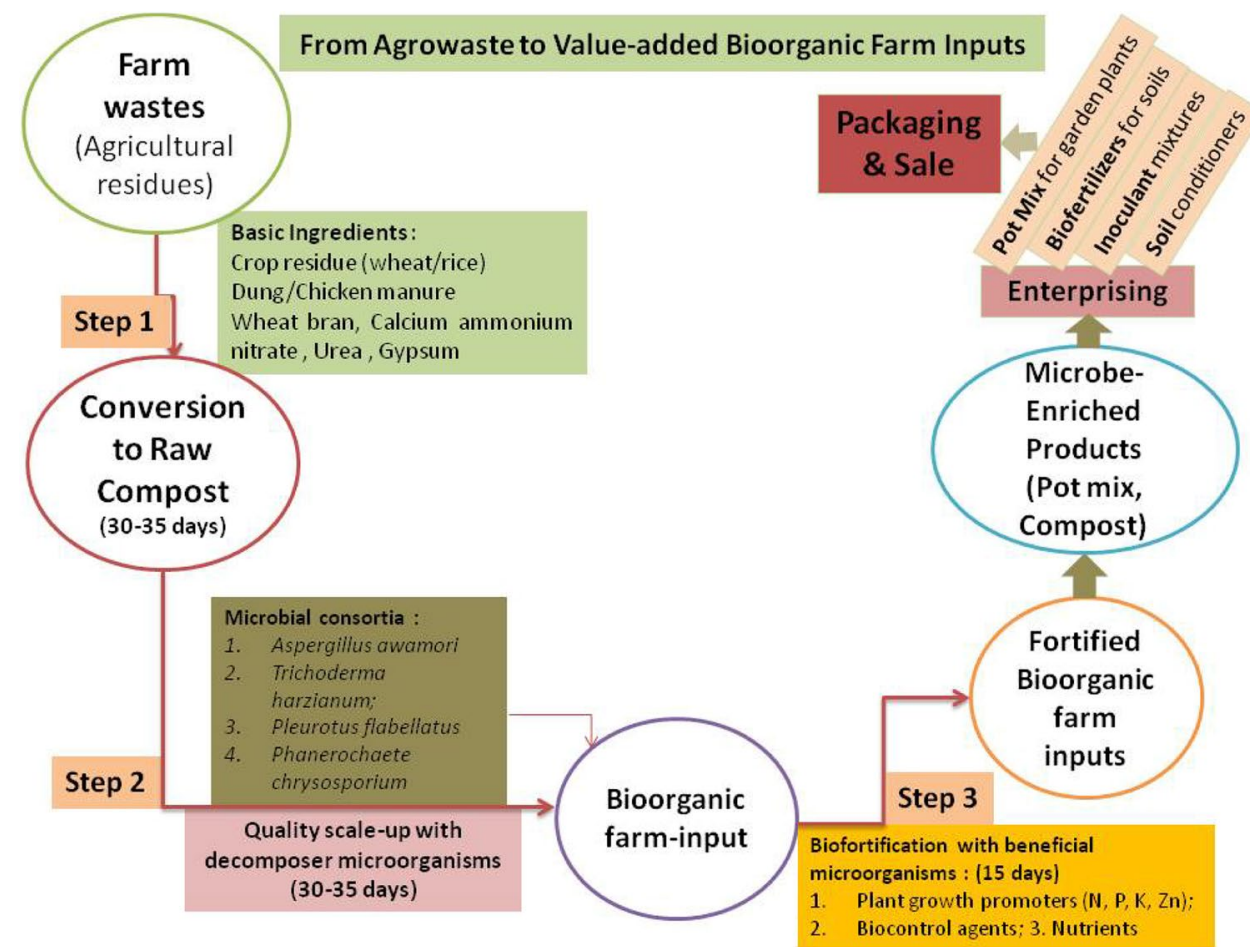

High input-based farming systems, in which chemical inputs play a major role, are becoming problematic owing to the loss of diversity of native phyto-, micro- and zoobiota and non-responsiveness of the soils (Shennan 2008). Excessive chemical usage has also led to serious imbalances in natural ecosystem of the soils and created threat to the fertility, structure and function of soils, crop intoxication, productivity losses and damaged harmony of crop-soil interactions (Aktar et al. 2009). Therefore, a farming system that promotes better utilization of farm residual resources and usage of low external inputs is the need of the time. Such a system will engage locally available sources with the farmers and make better use of their own field resources to obtain better results while minimizing dependency on high external costs on inputs. This is why, microbial technological interventions essentially need to be propagated into the farming communities to obtain better functional food, enhance soil organic matter by applying self-produced low-cost composts and microbiologically enriched farm inputs for strengthening field soils.

\section{Linking farmers with agrowaste bioconversion}

Adoption and adaptation of farmer-friendly microbe-mediated agrowaste bioconversion technology for composting among the grass-root stakeholders is a matter of perception and preference. Less awareness on soil and plant characters, lack of perception for linking up agricultural foods with human health, low tendency to adopt new technologies, short-sightedness towards long-term benefits and weak chain of awareness managers are the key factors that restrict direct penetration of valuable technologies among farmers. Awareness on these technologies and penetration into the farming communities either through ICT tools or by videos, learning materials or by technical demonstration kits may enhance technological adaptation (Karubanga et al. 2017). Some case studies on adaptation of pelletized compost from animal manure in the farming groups in Italy (Pampuro et al. 2018) and promotion of bioconversion technology in Indian farmers demanded targeted information campaigns, trainings, live product demonstrations and on-farm production applications to generate hands-on-experience. These efforts can yield desirable impacts on promotion of integrated farm management practices and soil fertility level to bring back countable changes among farming communities (Muller 2009). The outcome can be witnessed in terms of reducing dependency on high-cost chemical fertilizers, minimizing risk of pollutants due to residual effects of pesticides, lowering production cost of the crops, enhancing yield quality of production of commercial crops, ensuring increased fertility of farm soils and generating income after sale of the compost products (Aktar et al. 2009; Settle et al. 2012; Yadav et al. 2013). The concerns of direct farmer's benefits in reducing the input cost for crop production, improving soil and plant quality, creating wealth from waste through eco-enterprising of composted products and applying microbe-rich compost 
in organic farming practices are important. Therefore, the Indian government has shown keen interest in promoting adaptation of such environment- and agriculture-friendly practices in farmers through various developmental schemes and funding projects (https://nmsa.dac.gov.in/; http://midh. gov.in/; http://agricoop.nic.in/sites/default/files/OPG19 22016.pdf).

\section{Conclusion}

A reductionist approach towards the use of chemical fertilizers and pesticides is the need of the day across the world. Minimizing farm chemicals can solve various problems of the present-day agriculture, especially those which are directly linked with the soils, plants and human health and raise negative ecological impacts. Available post harvest crop residues create sanitation problems in the rural areas due to uncontrolled anaerobic degradation. While using excessive chemical fertilizers, farmers have almost forgotten to add organic carbon to the soils and this has resulted in lowering the carbon content of the soils over a time scale. Low organic carbon content soils usually become nonresponsive to support life of microorganisms, microflora, and fauna and thus lose biological functions. Live soil systems are the integrated part of the crop ecosystem to perform major ecological functions, which majorly include nutrient recycling, carbon sequestration, mineralization, availability of organic substances and volatiles. If crop residues are burnt in the farms, they disturb microbiota of the productive top-soil layers on one hand and pollute air quality on the other. With the help of microbial interventions and developing skills among the rural population, the raw residues can be transformed firstly into mushrooms of high nutrition value for nourishing food and subsequently, the spent waste can further be biologically converted into microbe-enriched compost having specific functional trait. The second option for the on-farm utilization of the crop residue is the needbase production of raw compost from the available residual resources. Its further bioconversion and fortification into bioorganic farm inputs with the help of potential microorganisms with multifunction can be of immense importance for the farming communities. One of the major benefits of using bioconversion technology for agrowaste bioconversion is to making feasible the availability of ready-to-use organic input in the soils. Secondly, this can also help to add desired microbial communities with specific functions, which, if added without any support of organic matter, may not flourish in the low-carbon soils. Thirdly, proper availability of bioorganic materials in the soil supports and enhances nutrient use efficiency of the soils and ensures proper availability of micronutrients for longer time durations. Apart from these direct benefits, there are furthermore benefits associated with application of compost and biofortified farm inputs. Presence of beneficial microbial communities in the soils makes their interactions feasible with the roots of the plants and thus, strengthens rhizosphere. This will help in the plant immunization and making crops resistant against pests and diseases and tolerance against abiotic stresses. In an integrated way, these microbe-mediated processes help improve ecological services around the plant roots and support soil fertility.

Acknowledgements DPS is thankful to the Rashtriya Krishi Vikas Yojna (RKVY) (Grant no. 2017-18), Government of Uttar Pradesh, India for funding support for the dissemination of agrowaste bioconversion technology. Funding support as a Grant no. DST/SSTP/ UP/38/2017-18(G) from the Department of Science and Technology, GOI, New Delhi for promotion of microbe-mediated practices in the fields in farmers of Eastern Uttar Pradesh is gratefully acknowledged. RP is thankful to DST for financial support under DST-Women Scientist Scheme-B (KIRAN Program) (Grant no. DST/ WOS-B/2017/67-AAS).

Open Access This article is distributed under the terms of the Creative Commons Attribution 4.0 International License (http://creativeco mmons.org/licenses/by/4.0/), which permits unrestricted use, distribution, and reproduction in any medium, provided you give appropriate credit to the original author(s) and the source, provide a link to the Creative Commons license, and indicate if changes were made.

\section{References}

Abhilash PC, Dubey RK, Tripathi V, Gupta VK, Singh HB (2016) Plant growth-promoting microorganisms for environmental sustainability. Trends Biotechnol 34:847-850. https://doi.org/10.1016/j. tibtech.2016.05.005

Achinas S, Achinas V, Euverink GJW (2017) A technological overview of biogas production from biowaste. Engineering 3:299-307. https://doi.org/10.1016/J.ENG.2017.03.002

Ahmad R, Jilani G, Arshad M, Zahir ZA, Khalid A (2007) Bio-conversion of organic wastes for their recycling in agriculture: an overview of perspectives and prospects. Ann Microbiol 57:471-479. https://doi.org/10.1007/BF03175343

Ahmad M, Taylor CR, Pink D, Burton KS, Eastwood DC, Bending GD (2010) Development of novel assays for lignin degradation: comparative analysis of bacterial and fungal lignin degraders. Mol Biosyst 6:815-821. https://doi.org/10.1007/BF03175343

Aktar MW, Sengupta D, Chowdhury A (2009) Impact of pesticides use in agriculture: their benefits and hazards. Interdiscip Toxicol 2:1-12. https://doi.org/10.2478/v10102-009-0001-7

Ali SS, Abomohra AEF, Sun J (2017) Effective bio-pretreatment of sawdust waste with a novel microbial consortium for enhanced biomethanation. Bioresour Technol 238:425-432. https://doi. org/10.1016/j.biortech.2017.03.187

Alves MCRA, Record E, Lomascolo A et al (2004) Highly efficient production of laccase by the basidiomycete Pycnoporus cinnabarinus. Appl Environ Microbiol 70:6379-6384. https://doi. org/10.1128/aem.70.11.6379-6384.2004

Anastasi A, Varese GC, Marchisio VF (2005) Isolation and identification of fungal communities in compost and vermicompost. Mycologia 97:33-44. https://doi.org/10.1080/15572536.2006.11832 836 
Awad NM, Khaled SM (2012) Maximizing effect of mineral fertilizers by compost and biofortified. Aust J Basic Appl Sci 6:482-493

Baig KS, Arshad M, Shaharoona B, Khalid A, Ahmed I (2012) Comparative effectiveness of Bacillus spp. possessing either dual or single growth-promoting traits for improving phosphorus uptake, growth and yield of wheat (Triticum aestivum L.). Ann Microbiol 62:1109-1119. https://doi.org/10.1007/s13213-011-0352-0

Benimelia CS, Castroa GR, Chailec AP, Amoroso MJ (2007) Lindane uptake and degradation by aquatic Streptomyces sp. strain M7. Int Biodeterior Biodegrad 59:148-155. https://doi.org/10.1016/j. ibiod.2006.07.014

Bernal MP, Alburquerque JA, Moral R (2009) Composting of animal manures and chemical criteria for compost maturity assessment. A review. Bioresour Technol 10:5444-5453. https://doi. org/10.1016/j.biortech.2008.11.027

Bertero M, de la Puente G, Sedran U (2012) Fuels from bio-oils: bio-oil production from different residual sources, characterization and thermal conditioning. Fuel 95:263-271. https://doi.org/10.1016/j. fuel.2011.08.041

Bhan S, Behera UK (2014) Conservation agriculture in India-problems, prospects and policy issues. Int Soil Water Conserv Res 2:1-12. https://doi.org/10.1016/S2095-6339(15)30053-8

Bholay A, Borkhataria BV, Jadhav PU, Palekar KS, Dhalkari MV, Nalawade PM (2012) Bacterial lignin peroxidase: a tool for biobleaching and biodegradation of industrial effluents. Univers J Environ Res Technol 2:58-64

Blum WEH (2013) Soil and land resources for agricultural production: general trends and future scenarios-a worldwide perspective. Int Soil Water Conserv Res 1:1-14. https://doi.org/10.1016/ S2095-6339(15)30026-5

Bohlke JK (2002) Groundwater recharge and agricultural contamination. Hydrogeol J 10:153-179. https://doi.org/10.1007/s1004 0-001-0183-3

Boulter JI, Trevors JT, Boland GJ (2002) Microbial studies of compost: bacterial identification, and their potential for turfgrass pathogen suppression. World J Microbiol Biotechnol 18:661-671. https:// doi.org/10.1023/A:1016827929432

Branca G, McCarthy N, Lipper L, Jolejole MC (2011) Climate smart agriculture: A synthesis of empirical evidence of food security and mitigation benefits from improved cropland management. Working Paper. Mitigation of Climate Change in Agriculture (MICCA) Programme, FAO, Rome. http://www.fao.org/clima techange/29764-0aa5796a4fb093b6cfdf05558c6dd20bb.pdf. Accessed 21 Dec 2018

Brandelli A, Sala L, Kalil SJ (2015) Microbial enzymes for bioconversion of poultry waste into added-value products. Food Res J 73:2-12. https://doi.org/10.1016/j.foodres.2015.01.015

Bustamante MA, Paredes C, Marhuenda-Egea FC, Pérez-Espinosa A, Bernal MP, Moral R (2008) Co-composting of distillery wastes with animal manures: carbon and nitrogen transformations in the evaluation of compost stability. Chemosphere 72:551-557. https ://doi.org/10.1016/j.chemosphere.2008.03.030

Cabuk A, Unal AT, Kolankaya N (2006) Biodegradation of cyanide by a white rot fungus, Trametes versicolor. Biotechnol Lett 28:1313-1317. https://doi.org/10.1007/s10529-006-9090-y

Carter MR (2002) Soil quality for sustainable land management: organic matter and aggregation interactions that maintain soil function. Agron J 94:38-47. https://doi.org/10.2134/agronj2002 .3800

Celik Y, Peker K (2009) Benefit/cost analysis of mushroom production for diversification of income in developing countries. Bulg J Agric Sci 15:228-237

Chandra R, Raj A, Purohit HJ, Kapley A (2007) Characterization and optimization of three potential aerobic bacterial strains for kraft lignin degradation from pulp paper waste. Chemosphere 67:839-846. https://doi.org/10.1016/j.chemosphere.2006.10.011
Chandra R, Singh R, Yadav S (2012) Effect of bacterial inoculum ratio in mixed culture for decolourization and detoxification of pulp paper mill effluent. J Chem Technol Biotechnol 87:436-444. https://doi.org/10.1002/jctb. 2758

Chang ST (2008) Overview of mushroom cultivation and utilization as functional foods. In: Cheung PCK (ed) Mushrooms as functional foods. Wiley, New York, pp 1-32. https://doi.org/10.1002/97804 70367285.ch1

Chen Y, Guo R, Li Y-C, Liu H, Zhan TL (2016) A degradation model for high kitchen waste content municipal solid waste. Waste Manag 58:376-385. https://doi.org/10.1016/j.wasma n.2016.09.005

Choudhary M, Sharma PC, Jat HS, Nehra V, McDonald AJ, Garg N (2016) Crop residue degradation by fungi isolated from conservation agriculture fields under rice-wheat system of NorthWest India. Int J Recycl Org Waste Agric 5:349-360. https://doi. org/10.1007/s40093-016-0145-3

Clara L, Fatma R, Viridiana A, Liesl W (2017) Soil organic carbon: the hidden potential. FAO. http://www.fao.org/3/a-i6937e.pdf. Accessed 8 Nov 2018

de Souza WR (2013) Microbial degradation of lignocellulosic biomass. In: Chandel AK, da Silva SS (eds) Sustainable degradation of lignocellulosic biomass-techniques, applications and commercialization. INTECH, Rijieka. https://doi.org/10.5772/54325 (ISBN 978-953-51-1119-1)

Eida MF, Nagaoka T, Wasaki J, Kouno K (2012) Isolation and characterization of cellulose-decomposing bacteria inhabiting sawdust and coffee residue composts. Microbe Environ 27:226-233. https ://doi.org/10.1264/jsme2.ME11299

Erickson MC, Liao J, Ma L, Jiang X, Doyle MP (2009) Inactivation of Salmonella spp. in cow manure composts formulated to different initial C:N ratios. Bioresour Technol 100:5898-5903. https://doi. org/10.1016/j.biortech.2009.06.083

FAO (2017) The future of food and agriculture - trends and challenges, Rome. http://www.fao.org/3/a-i6583e.pdf. Accessed 18 Dec 2018

Fenga CL, Zenga GM, Huanga DL, Hua S, MeiHua Z, Cui L, Huanga C, Weia Z, Li N (2011) Effect of ligninolytic enzymes on lignin degradation and carbon utilization during lignocellulosic waste composting. Process Biochem 46:1515-1520. https://doi. org/10.1016/j.procbio.2011.01.038

Franke-Whittle IH, Confalonieri A, Insam H, lmilch MS, Körner I (2014) Changes in the microbial communities during co-composting of digestates. Waste Manag 34:632-641. https://doi. org/10.1016/j.wasman.2013.12.009

Frison EA, Cherfas J, Hodgkin T (2011) Agricultural biodiversity is essential for a sustainable improvement in food and nutrition security. Sustainability 3:238-253. https://doi.org/10.3390/su301 0238

Gaind S, Nain L (2007) Chemical and biological properties of wheat soil in response to paddy straw incorporation and its biodegradation by fungal inoculants. Biodegradation 18:495-503. https:// doi.org/10.1007/s10532-006-9082-6

Gajalakshmi S, Abbasi SA (2008) Solid waste management by composting: state of the art. Crit Rev Environ Sci Technol 38:311340. https://doi.org/10.1080/10643380701413633

Galitskaya P, Biktasheva I, Kuryntseva P, Selivanovskaya S (2016) Suppressive properties of composts may be improved by microbial inoculation. Int J Adv Biotechnol Res 7:773-783

Gattinger A, Muller A, Haeni M, Skinner C, Fliessbach A, Buchmann N, Mäder P, Stolze M, Smith P, El-Hage Scialabba N, Niggli U (2012) Enhanced top soil carbon stocks under organic farming. Proc Nat Acad Sci USA 109:18226-18231. https://doi. org/10.1073/pnas.1209429109

Gautam SP, Bundela PS, Pandey AK, Jamaluddin Awasthi MK, Sarsaiya S (2012) Diversity of cellulolytic microbes and the biodegradation of municipal solid waste by a potential strain. Int 
J Microbiol. https://doi.org/10.1155/2012/325907 (article ID 325907)

Gliessman SR, Rosemeyer M (2010) The conversion to sustainable agriculture-principles, processes and practices. CRC Press, Boca Raton

Godde CM, Thorburn PJ, Biggs JS, Meier EA (2016) Understanding the impacts of soil, climate, and farming practices on soil organic carbon sequestration: a simulation study in Australia. Front Plant Sci 7:661. https://doi.org/10.3389/fpls.2016.00661

Godfray HCJ, Garnett T (2014) Food security and sustainable intensification. Philos Trans R Soc Lond B Biol Sci 5:369. https://doi. org/10.1098/rstb.2012.0273

Gomez F, Sartaj M (2014) Optimization of field scale biopiles for bioremediation of petroleum hydrocarbon contaminated soil at low temperature conditions by response surface methodology (RSM). Int Biodeterior Biodegrad 89:103-109. https://doi. org/10.1016/j.ibiod.2014.01.010

Gougoulias C, Clark JM, Shaw LJ (2014) The role of soil microbes in the global carbon cycle: tracking the below-ground microbial processing of plant-derived carbon for manipulating carbon dynamics in agricultural systems. J Sci Food Agric 94:23622371. https://doi.org/10.1002/jsfa.6577

Han X, Xu C, Dungait JAJ, Bol R, Wang X, Wu W, Meng F (2017) Straw incorporation increases crop yield and soil organic carbon sequestration but varies under different natural conditions and farming practices in China: a system analysis. Biogeosci Discuss. https://www.biogeosciences-discuss.net/bg-2017-493/bg-2017493.pdf. Accessed 21 Dec 2018

Harazano K, Yamashita M, Shinzato N et al (2003) Isolation and characterization of aromatics degrading microorganisms from the gut of the lower termite Coptotermes formosanus. Biosci Biotechnol Biochem 67:889-892

Himmel ME, Xu Q, Luo Y, Ding S-Y, Lamed R, Bayer EA (2010) Microbial enzyme systems for biomass conversion: emerging paradigms. Biofuels 1:323-341. https://doi.org/10.4155/ bfs.09.25

Hobbs PR, Sayre K, Gupta R (2008) The role of conservation agriculture in sustainable agriculture. Philos Trans R Soc Lond B Biol Sci 363:543-555. https://doi.org/10.1098/rstb.2007.2169

Hongsibsong S, Sittitoon N, Sapbamrer R (2017) Association of health symptoms with low-level exposure to organophosphates, DNA damage, AChE activity, and occupational knowledge and practice among rice, corn, and double-crop farmers. J Occup Health 59:165-176. https://doi.org/10.1539/joh.16-0107-OA

Hoornweg D, Thomas L, Otten L (2000) Composting and its applicability in developing countries. Published for the Urban Development Division The World Bank, Washington DC. Working Paper Series. 8. Urban Waste Management (2000)

Hossard L, Philibert A, Bertrand M et al (2014) Effects of halving pesticide use on wheat production. Sci Rep 4:4405. https://doi. org/10.1038/srep04405

Huang HL, Zeng GM, Jiang RQ, Yuan XZ, Yu M (2009) Fluorescence spectroscopy characteristics of humic acid by inoculating white-rot fungus during different phases of agricultural waste composting. J Cent South Univ Technol 16:440-443. https://doi. org/10.1007/s11771-009-0074-7

Huang DL, Zeng GM, Feng CL et al (2010) Changes of microbial population structure related to lignin degradation during lignocellulosic waste composting. Bioresour Technol 101:4062-4067. https://doi.org/10.1016/j.biortech.2009.12.145

Huber A, Praznik W (2004) Identification and quantification of renewable crop materials. In: Stevens CV, Verhe R (eds) Renewable bioresources: Scope and modifications for non-food applications. Wiley, England

Ichida JM, Krizova L, LeFevre CA, Keener HM, Elwell DL, Burtt EH (2001) Bacterial inoculum enhances keratin degradation and biofilm formation in poultry compost. J Microbiol Methods 47:199-208

Ilyin VK, Smirnov IA, Soldatov PE, Korniushenkova IN, Grinin AS, Lykov IN, Safronova SA (2004) Microbial utilisation of natural organic wastes. Acta Astronaut 54:357-361

Jaishankar M, Tseten T, Anbalagan N, Mathew BB, Beeregowda KN (2014) Toxicity, mechanism and health effects of some heavy metals. Interdiscip Toxicol 7:60-72. https://doi.org/10.2478/ intox-2014-0009

Jorgensen H, Errikson T, Børjesson J, Tjerneld F, Olsson L (2003) Purification and characterization of five cellulases and one xylanases from Penicillium brasilianum IBT 20888. Enzyme Microb Technol 32:851-861

Jurak E, Kabel MA, Gruppen H (2014) Carbohydrate composition of compost during composting and mycelium growth of Agaricus bisporus. Carbohydr Polym 101:281-288. https://doi. org/10.1016/j.carbpol.2013.09.050

Jurak E, Punt AM, Arts W, Kabel MA, Gruppen H (2015) Fate of carbohydrates and Lignin during composting and mycelium growth of Agaricus bisporus on wheat straw based compost. PLoS One 10:e0138909. https://doi.org/10.1371/journ al.pone.0138909

Kamran S, Shahid I, Baig DN, Rizwan M, Malik KA, Mehnaz S (2017) Contribution of zinc solubilizing bacteria in growth promotion and zinc content of wheat. Front Microbiol 8:2593. https://doi. org/10.3389/fmicb.2017.02593

Karimi AM, Yaghmaei S (2016) Biochemical production of bioenergy from agricultural crops and residue in Iran. Waste Manag 52:375-394. https://doi.org/10.1016/j.wasman.2016.03.025

Karubanga G, Kibwika P, Okry F, Sseguya H (2017) How farmer videos trigger social learning to enhance innovation among smallholder rice farmers in Uganda. Cogent Food Agric 3:1368105. https://doi.org/10.1080/23311932.2017.1368105

Kersten P, Cullen D (2007) Extracellular oxidative systems of the lignin-degrading Basidiomycete Phanerochaete chrysosporium. For Genet Biol 44:77-87. https://doi.org/10.1016/j. fgb.2006.07.007

Kesavan PC, Swaminathan MS (2008) Strategies and models for agricultural sustainability in developing Asian countries. Philos Trans R Soc Lond B Biol Sci 363:877-891. https://doi. org/10.1098/rstb.2007.2189

Khatri N, Tyagi S (2015) Influences of natural and anthropogenic factors on surface and groundwater quality in rural and urban areas. Front Life Sci 8:23-39. https://doi.org/10.1080/21553 769.2014.933716

Kibblewhite MG, Ritz K, Swift MJ (2008) Soil health in agricultural systems. Philos Trans R Soc Lond B Biol Sci 363:685-701. https ://doi.org/10.1098/rstb.2007.2178

Kumar BL, Sai Gopal DVR (2015) Effective role of indigenous microorganisms for sustainable environment. 3 Biotech 5:867-876. https://doi.org/10.1007/s13205-015-0293-6

Kumar AK, Sharma S (2017) Recent updates on different methods of pretreatment of lignocellulosic feedstocks: a review. Bioresour Bioprocess 4:7. https://doi.org/10.1186/s40643-017-0137-9

Kumar S, Chand G, Srivastava JN, Md Shamshe A (2014) Postharvest technology of button mushroom: a socio-economic feasibility. J Postharvest Technol 2:136-145

Kung CC, Kong F, Choi Y (2015) Pyrolysis and biochar potential using crop residues and agricultural wastes in China. Ecol Ind 51:139145. https://doi.org/10.1016/j.ecolind.2014.06.043

Lal R (2015) Restoring soil quality to mitigate soil degradation. Sustainability 7:5875-5895. https://doi.org/10.3390/su7055875

Liers C, Ullrich R, Steffen KT, Hatakka A, Hofrichter M (2006) Mineralization of ${ }^{14} \mathrm{C}$-labelled synthetic lignin and extracellular enzyme activities of the wood-colonizing ascomycetes Xylaria 
hypoxylon and Xylaria polymorpha. Appl Microbiol Biotechnol 69:573-579. https://doi.org/10.1007/s00253-005-0010-1

Lim SL, Wu TY, Lim PN, Shak KPY (2015) The use of vermicompost in organic farming: overview, effects on soil and economics. J Sci Food Agric 95:1143-1156. https://doi.org/10.1002/jsfa.6849

Loow Y-L, Wu TY, Tan KA, Lim YS, Siow LF, Md Jahim J, Mohammad AW, Teoh WH (2015) Recent advances in the application of inorganic salt pretreatment for transforming lignocellulosic biomass into reducing sugars. J Agric Food Chem 63:8349-8363. https://doi.org/10.1021/acs.jafc.5b01813

Loow Y-L, New EK, Yang GH, Ang LY, Foo LYW, Wu TY (2017a) Potential use of deep eutectic solvents to facilitate lignocellulosic biomass utilization and conversion. Cellulose 24:3591-3618. https://doi.org/10.1007/s10570-017-1358-y

Loow Y-L, Wu TY, Lim YS, Tan KA, Siow LF, Md Jahim J, Mohammad AW (2017b) Improvement of xylose recovery from the stalks of oil palm fronds using inorganic salt and oxidative agent. Energy Convers Manag 138:248-260. https://doi.org/10.1016/j. enconman.2016.12.015

Lorenz M, Fürst C, Thiel E (2013) A methodological approach for deriving regional crop rotations as basis for the assessment of the impact of agricultural strategies using soil erosion as example. $\mathbf{J}$ Environ Manag. https://doi.org/10.1016/j.jenvman.2013.04.050

Lori M, Symnaczik S, Mäder P, De Deyn G, Gattinger A (2017) Organic farming enhances soil microbial abundance and activity - a meta-analysis and meta-regression. PLoS One 12:e0180442. https://doi.org/10.1371/journal.pone.0180442

Louis BP, Maron P-A, Menasseri-Aubry S, Sarr A, Lévêque J, Mathieu O et al (2016) Microbial diversity indexes can explain soil carbon dynamics as a function of carbon source. PLoS One 11:e0161251. https://doi.org/10.1371/journal.pone.0161251

Ma A, Zhuang X, Wu J, Cui M, Lv D, Liu C, Zhuang G (2013) Ascomycota members dominate fungal communities during straw residue decomposition in arable soil. PLoS One 8:e66146. https ://doi.org/10.1371/journal.pone.0066146

Malusá E, Sas-Paszt L, Ciesielska J (2012) Technologies for beneficial microorganisms inocula used as biofertilizers. Sci World J. https ://doi.org/10.1100/2012/491206 (article ID 491206)

Marcela CP, Eduardo J, Azevedo C et al (2017) Advances in eco-efficient agriculture: the plant-soil mycobiome. Agriculture 7:14. https://doi.org/10.3390/agriculture7020014

Marshall E, Nair N (2009) Make money by growing mushrooms. Food and Agriculture Organization of the United Nations (FAO), Rome

Martens W, Böhm R (2009) Overview of the ability of different treatment methods for liquid and solid manure to inactivate pathogens. Bioresour Technology. 100:5374-5378. https://doi. org/10.1016/j.biortech.2009.01.014

Martinez AT (2002) Molecular biology and structure-function of lignin-degrading heme peroxidases. Enzyme Microb Technol 30:425-432. https://doi.org/10.1016/S0141-0229(01)00521-X

Martín-Gil J, Navas-Gracia LM, Gómez-Sobrino E, Correa-Guimaraes A, Hernández-Navarro S, Sánchez-Báscones M, del Carmen Ramos-Sánchez M (2008) Composting and vermicomposting experiences in the treatment and bioconversion of asphaltens from the prestige oil spill. Bioresour Technol 99:1821-1829. https://doi.org/10.1016/j.biortech.2007.03.031

Masran R, Zanirun Z, Bahrin EK, Ibrahim MF, Lai Yee P, Abd-Aziz S (2016) Harnessing the potential of ligninolytic enzymes for lignocellulosic biomass pretreatment. Appl Microbiol Biotechnol 100:5231-5246. https://doi.org/10.1007/s00253-016-7545-1

Meena VS, Maurya BR, Verma JP (2014) Does a rhizospheric microorganism enhance $\mathrm{K}^{+}$availability in agricultural soils? Microbiol Res 169:337-347. https://doi.org/10.1016/j.micres.2013.09.003

Meena KK, Sorty AM, Bitla UM, Choudhary K, Gupta P, Pareek A, Singh DP, Prabha R, Sahu PK, Gupta VK, Singh HB, Krishanani
KK, Minhas PS (2017) Abiotic stress responses and microbemediated mitigation in plants: the omics strategies. Front Plant Sci. https://doi.org/10.3389/fpls.2017.00172

Mielenz JR (2001) Ethanol production from biomass: technology and commercialization status. Curr Opin Microbiol 4:324-329. https ://doi.org/10.1016/S1369-5274(00)00211-3

Miki T, Ushio M, Fukui S, Kondoh M (2010) Functional diversity of microbial decomposers facilitates plant coexistence in a plant-microbe-soil feedback model. Proc Nat Acad Sci USA 32:14251-14256. https://doi.org/10.1073/pnas.0914281107

Mishra V, Jana AK (2017) Fungal pretreatment of sweet sorghum bagasse with combined $\mathrm{CuSO}_{4}$-gallic acid supplement for improvement in lignin degradation, selectivity, and enzymatic saccharification. Appl Biochem Biotechnol 183:200-217. https ://doi.org/10.1007/s13205-017-0719-4

Mohanty MK, Behera BK, Jena SK, Srikanth S, Mogane C, Samal S, Behera AA (2013) Knowledge attitude and practice of pesticide use among agricultural workers in Puducherry, South India. J Forensic Leg Med 20:1028-1031. https://doi.org/10.1016/j. jflm.2013.09.030

Mohler CL, Johnson SE (2009) Crop rotation on organic farms: a planning manual. Plant and Life Science Publishing (PALS), New York

Moreno AD, Ibarra D, Alvira P, Tomás-Pejó E, Ballesteros M (2015) A review of biological delignification and detoxification methods for lignocellulosic bioethanol production. Crit Rev Biotechnol 35:342-354. https://doi.org/10.3109/07388551.2013.878896

Mosier N, Wyman CE, Dale BE, Elander R, Lee YY, Holtzapple M, Ladisch M (2005) Features of promising technologies for pretreatment of lignocellulosic biomass. Bioresour Technol 96:673686. https://doi.org/10.1016/j.biortech.2004.06.025

Mouthier TMB, Kilic B, Vervoort P, Gruppen H, Kabel MA (2017) Potential of a gypsum-free composting process of wheat straw for mushroom production. PLoS One 12:e0185901. https://doi. org/10.1371/journal.pone.0185901

Msangi S (2012) Biofuels and a green economy. IFPRI, Washington, DC (source Internet). http://www.ifpri.org/blog/biofuels-andgreen-economy. Accessed 18 Dec 2018

Mshandete AM, Cuff J (2008) Cultivation of three types of indigenous wild edible mushrooms: Coprinus cinereus, Pleurotus flabellatus and Volvariella volvacea on composted sisal decortications residue in Tanzania. Afr J Biotechnol 7:4551-4562

Muller A (2009) Benefits of organic agriculture as a climate change and mitigation strategy for developing countries. Environment for development, discussion paper series (2009). http://www.ifr. ac.uk/waste/reports/benefitsoforganicagriculture.pdf. Accessed 18 Dec 2018

Muthu D, Venkata Subramanian C, Ramakrishnan K, Sasidhar J (2017) Production of biogas from wastes blended with cow dung for electricity generation- a case study. IOP Conf Ser Earth Environ Sci 80:01205. https://doi.org/10.1088/1755-1315/80/1/012055

Muttalib SAA, Ismail SNS, Praveena SM (2016) Application of effective microorganism (EM) in food waste composting: a review. Asia Pac Environ Occup Health J 2:37-47

Nagavallemma KP, Wani SP, Stephane L, Padmaja VV, Vineela C, Babu Rao M, Sahrawat KL (2004) Vermicomposting: recycling wastes into valuable organic fertilizer. Global theme on agrecosystems report no. 8. An open access journal published by ICRISAT, p 20

Nair J, Okamitsu K (2012) Microbial inoculants for small scale composting of putrescible kitchen wastes. Waste Manag 30:977-982. https://doi.org/10.1016/j.wasman.2010.02.016

Naresh RK (2013) Rice residues: from waste to wealth through environment friendly and innovative management solutions, it's effects on soil properties and crop productivity. Int J Life Sci Biotechnol Pharma Res 2:133-141 
Ng LC, Sariah M, Radziah O, Zainal Abidin MA, Sariam O (2016) Development of microbial-fortified rice straw compost to improve plant growth, productivity, soil health, and rice blast disease management of aerobic rice. Compost Sci Util 24:86097

Nieves RA, Ehrman CI, Adney WS, Elander RT, Himmel ME (1998) Technical communication: survey and analysis of commercial cellulase preparations suitable for biomass conversion to ethanol. World J Microbiol Biotechnol 14:301-304. https://doi. org/10.1023/A:1008871205580

Novinscak A, Surette C, Allain C, Filion M (2008) Application of molecular technologies to monitor the microbial content of biosolids and composted biosolids. Water Sci Technol 57:471-477. https://doi.org/10.2166/wst.2008.019

Osteen C, Jessica G, Utpal V (2012) Agricultural resources and environmental indicators. EIB-98, U.S. Department of Agriculture, Economic Research Service

Pal S, Sarkar S, Banerjee R, Chanda S, Das P et al (2010) Effectiveness of inoculation with isolated Geobacillus strains in the thermophilic stage of vegetable waste composting. Bioresour Technol 101:2892-2895. https://doi.org/10.1016/j.biortech.2009.11.095

Pallavi Chandra D, Sharma AK (2017) Commercial microbial products: exploiting beneficial plant-microbe interaction. In: Singh DP, Singh HB, Prabha R (eds) Plant-microbe interactions in agro-ecological perspectives. Springer, Singapore. https://doi. org/10.1007/978-981-10-6593-4_25

Pampuro N, Dinuccio E, Balsari P, Cavallo E (2016) Evaluation of two composting strategies for making pig slurry solid fraction suitable for pelletizing. Atmos Pollut Res 7:288-293. https://doi. org/10.1016/j.apr.2015.10.001

Pampuro N, Bagagiolo G, Priarone PC, Cavallo E (2017a) Effects of pelletizing pressure and the addition of woody bulking agents on the physical and mechanical properties of pellets made from composted pig solid fraction. Powder Technol 311:112-119. https://doi.org/10.1016/j.powtec.2017.01.092

Pampuro N, Bertora C, Sacco D, Dinuccio E, Grignani C, Balsari P, Cavallo E, Bernal MP (2017b) Fertilizer value and GHG emissions of pellets from the solid fraction of pig slurry compost. $\mathrm{J}$ Agric Sci 155:1646-1658. https://doi.org/10.1017/S002185961 $700079 \mathrm{X}$

Pampuro N, Caffaro F, Cavallo E (2018) Reuse of animal manure: a case study on stakeholders' perceptions about pelletized compost in Northwestern Italy. Sustainability 10:2028. https://doi. org/10.3390/su10062028

Pan I, Dam B, Sen SK (2012) Composting of common organic wastes using microbial inoculants. 3 Biotech 2:127-134. https://doi. org/10.1007/s13205-011-0033-5

Parnell JJ, Berka R, Young HA, Sturino JM, Kang Y, Barnhart DM, DiLeo MV (2016) From the lab to the farm: an industrial perspective of plant beneficial microorganisms. Front Plant Sci 7:1110. https://doi.org/10.3389/fpls.2016.01110

Patchaye M, Sundarkrishnan B, Tamilselvan S, Sakthivel N (2018) Microbial management of organic waste in agroecosystem. In: Panpatte DG et al (eds) Microorganisms for green revolution. Book series microorganisms for sustainability, vol 7, pp 45-73. https://doi.org/10.1007/978-981-10-7146-1_3

Pathma J, Sakthivel N (2012) Microbial diversity of vermicompost bacteria that exhibit useful agricultural traits and waste management potential. Springerplus 1:26. https://doi. org/10.1186/2193-1801-1-26

Patra NK, Babu SC (2017) Mapping Indian agricultural emissions. Lessons for food system transformations and policy support for climate-smart agriculture. IFPRI discussion paper 01660

Perez J, Munoz-Dorado J, de la Rubia T, Martinez J (2014) Biodegradation and biological treatments of cellulose, hemicellulose and lignin: an overview. Int Microbiol 5:53-63. https://doi. org/10.1007/s10123-002-0062-3
Petre M, Petre V, Rusea I (2014) Microbial composting of fruit tree wastes through controlled submerged fermentation. Ital J Agron 9:152-156. https://doi.org/10.4081/ija.2014.610

Phalan B, Green R, Balmford A (2014) Closing yield gaps: perils and possibilities for biodiversity conservation. Philos Trans R Soc Lond B Biol Sci 369:20120285. https://doi.org/10.1098/ rstb.2012.0285

Phan CW, Sabaratnam V (2012) Potential uses of spent mushroom substrate and its associated lignocellulosic enzymes. Appl Microbiol Biotechnol 96:863-873. https://doi.org/10.1007/s0025 3-012-4446-9

Pingali PL (2014) Green revolution: impacts, limits, and the path ahead. Proc Natl Acad Sci USA 109:12302-12308. https://doi. org/10.1073/pnas.0912953109

Pleissner D, Kwan TH, Lin CSK (2013) Fungal hydrolysis in submerged fermentation for food waste treatment and fermentation feedstock preparation. Bioresour Technol 158:48-54. https://doi. org/10.1016/j.biortech.2014.01.139

Popp J, Pető K, Nagy J (2013) Pesticide productivity and food security. A review. J Agron Sustain Dev 33:243. https://doi.org/10.1007/ s13593-012-0105-X

Pothiraj C, Kanmani P, Balaji P (2006) Bioconversion of lignocellulose materials. Mycobiology 34:159-165. https://doi.org/10.4489/ MYCO.2006.34.4.159

Power AG (2010) Ecosystem services and agriculture: tradeoffs and synergies. Philos Trans R Soc Lond B Biol Sci 365:2959-2971. https://doi.org/10.1098/rstb.2010.0143

Pradhan P, Fischer G, van Velthuizen H, Reusser DE, Kropp JP (2015) Closing yield gaps: how sustainable can we be? PLoS One 10:e0129487. https://doi.org/10.1371/journal.pone.0129487

Pramanik P, Maity A, Mina U (2013) Multi-enterprise agriculture system. Int J Environ Sci Dev Monitor 4:86-88

Prassad S, Singh A, Joshi HC (2007) Ethanol as an alternative fuel from agricultural, industrial and urban residues. Resour Conserv Recycl 50:1-39. https://doi.org/10.1016/j.resconrec.2006.05.007

Pretty J, Bharucha ZP (2014) Sustainable intensification in agricultural systems. Ann Bot 114:1571-1596. https://doi.org/10.1093/aob/ mcu205

Pugliese M, Liu B, Gullino ML, Garibaldi A (2011) Microbial enrichment of compost with biological control agents to enhance suppressiveness to four soil-borne diseases in greenhouse. J Plant Dis Prot 118:45-50. https://doi.org/10.1007/BF03356380

Raj A, Chandra R, Reddy MMK, Hemant JP, Kapley A (2007) Biodegradation of kraft lignin by a newly isolated bacterial strain, Aneurinibacillus aneurinilyticus from the sludge of a pulp paper mill. World J Microbiol Biotechnol 23:793-799. https://doi. org/10.1007/s11274-006-9299-x

Rashid MI, Mujawar LH, Shahzad T, Almeelbi T, Ismail IMI, Oves M (2016) Bacteria and fungi can contribute to nutrients bioavailability and aggregate formation in degraded soils. Microbiol Res 183:26-41. https://doi.org/10.1016/j.micres.2015.11.007

Reddy CA, Saravanan RS (2013) Polymicrobial multi-functional approach for enhancement of crop productivity. Adv Appl Microbiol 82:53-113. https://doi.org/10.1016/B978-0-12-40767 9-2.00003-X

Ribeiro NDQ, Souza TP, Costa LMAS, Castro CPD, Dias ES (2017) Microbial additives in the composting process. Ciência e Agrotecnologia 41:159-168. https://doi.org/10.1590/1413-70542 017412038216

Romano E, Brambilla M, Bisaglia C, Pampuro N, Foppa Pedretti E, Cavallo E (2014) Pelletization of composted swine manure solid fraction with different organic co-formulates: effect of pellet physical properties on rotating spreader distribution patterns. Int J Recycl Org Waste Agric 3:101-111. https://doi.org/10.1007/ s40093-014-0070-2 
Romero E, Esperanza M, García-Guinea J, Martínez ÁT, Martínez MJ (2007) An anamorph of the white-rot fungus Bjerkandera adusta capable of colonizing and degrading compact disc components. FEMS Microbiol Lett 275:122-129. https://doi.org/10 $.1111 /$ j.1574-6968.2007.00876.x

Ros M, Raut I, Santisima-Trinidad AB, Pascual JA (2017) Relationship of microbial communities and suppressiveness of Trichoderma fortified composts for pepper seedlings infected by Phytophthora nicotianae. PLoS One 12:e0174069. https://doi.org/10.1371/ journal.pone.0174069

Rubio R, Perez-Murcia MD, Agullo E, Bustamante MA, Sanchez C, Paredes C, Moral R (2013) Recycling of agro-food wastes into vineyards by composting: agronomic validation in field conditions. Commun Soil Sci Plant Anal 44:502-516. https://doi. org/10.1080/00103624.2013.744152

Sahu PK, Singh DP, Prabha R, Meena KK, Abhilash PC (2018) Connecting microbial capabilities with the soil and plant health: options for agricultural sustainability. Ecol Indic. https://doi. org/10.1016/j.ecolind.2018.05.084

Sánchez C (2009) Lignocellulosic residues: biodegradation and bioconversion by fungi. Biotechnol Adv 27:185-194. https://doi. org/10.1016/j.biotechadv.2008.11.001

Sanz-Cobena A, Lassaletta L, Aguilera E, Prado AD, Garnier J, Billen G, Iglesias A, Sánchez B, Guardia G, Abalos RD, Plaza-Bonilla D, Puigdueta-bartolomé I, Moral R, Galán E, Arriaga H, Merino P, Infante-Amate J, Meijide A, Pardo G, Álvaro-Fuentes J, Gilsanz C, Báez D, Doltra J, González-Ubierna S, Cayuela ML, Menéndez S, Díaz-Pinés E, Le-Noë J, Quemada M, Estellés F, Calvet S, Grinsven HJM, Van Westhoek H, Sanz MJ, Gimeno BS, Vallejo A, Smith P (2017) Strategies for greenhouse gas emissions mitigation in Mediterranean agriculture: a review. Agric Ecosyst Environ 238:5-24. https://doi.org/10.1016/j. agee.2016.09.038

Sarkar P, Chourasia R (2017) Bioconversion of organic solid wastes into biofortified compost using a microbial consortium. Int $\mathbf{J}$ Recycl Org Waste Agric 6:321-334. https://doi.org/10.1007/ s40093-017-0180-8

Schloss PD, Hay AG, Wilson DB, Walker LP (2003) Tracking temporal changes of bacterial community fingerprints during the initial stages of composting. FEMS Microbiol Ecol 46:1-9. https://doi. org/10.1016/S0168-6496(03)00153-3

Schröder P, Beckers B, Daniels S, Gnädinger F, Maestri E, Marmiroli N, Mench M, Millan R, Obermeier MM, Oustriere N, Persson T, Poschenrieder C, Rineau F, Rutkowska B, Schmid T, Szulc W, Witters N, Sæbø A (2018) Intensify production, transform biomass to energy and novel goods and protect soils in Europe-a vision how to mobilize marginal lands. Sci Total Environ 616617:1101-1123. https://doi.org/10.1016/j.scitotenv.2017.10.209

Seremesic S, Milosev D, Djalovic I, Zeremski T, Ninkov J (2011) Management of soil organic carbon in maintaining soil productivity and yield stability of winter wheat. Plant Soil Environ 57:216-221

Settle W, Soumaré M, Sarr M, Garba MH, Poisot AS (2012) Reducing pesticide risks to farming communities: cotton farmer field schools in Mali. Philos Trans R Soc Lond B Biol Sci 369:20120277. https://doi.org/10.1098/rstb.2012.0277

Seyedbagheri MM (2010) Compost: production, quality, and use in commercial agriculture. CIS 1175 . University of Idaho. USA. http://cals.uidaho.edu/edcomm/pdf/CIS/CIS1175.pdf. Accessed 18 Dec 2018

Sharma SB, Sayyed RZ, Trivedi MH, Gobi TA (2013) Phosphate solubilizing microbes: sustainable approach for managing phosphorus deficiency in agricultural soils. Springerplus 2:587. https:// doi.org/10.1186/2193-1801-2-587
Shennan C (2008) Biotic interactions, ecological knowledge and agriculture. Philos Trans R Soc Lond B Biol Sci 363:717-739. https ://doi.org/10.1098/rstb.2007.2180

Shilev S, Naydenov M, Vancheva V, Aladjadjiyan A (2007) Composting of food and agricultural wastes. In: Oreopoulu V (ed) Utilization of by-products and treatment of waste in the food industry. Springer, Boston, pp 283-301. https://doi.org/10.1007/978-0387-35766-9_15

Shrestha S, Fonoll X, Khanal SK, Raskin L (2017) Biological strategies for enhanced hydrolysis of lignocellulosic biomass during anaerobic digestion: current status and future perspectives. Bioresour Technol 245(Pt-A):1245-1257. https://doi.org/10.1016/j.biort ech.2017.08.089

Siddiqui Y, Meon S, Ismail MR, Ali A (2008) Trichoderma-fortified compost extracts for the control of choanephora wet rot in okra production. Crop Prot 27:385-390. https://doi.org/10.1016/j. cropro.2007.07.002

Singh MP (2000) Biodegradation of lignocellulosic wastes through cultivation of Pleurotus sajor-caju. In: van Griensven LJLD (ed) Science and cultivation of edible fungi. CABI, Rotterdam, pp 517-521

Singh S, Nain L (2015) Microorganisms in the conversion of agricultural wastes to compost. Proc Ind Natl Sci Acad 80:473-481. https://doi.org/10.16943/ptinsa/2014/v80i2/7

Singh DP, Prabha R (2017) Bioconversion of agricultural wastes into high value biocompost: a route to livelihood generation for farmers. Adv Recycl Waste Manag 2:3. https://doi. org/10.4172/2475-7675.1000137

Singh A, Sharma S (2002) Composting of a crop residue through treatment with microorganisms and subsequent vermicomposting. Bioresour Technol 85:107-111

Singh R, Bishnoi DK, Singh A (2010) Cost benefit analysis and marketing of mushroom in Haryana. Agric Econ Res Rev 23:165-171

Sinha RK, Valani D, Sinha S, Singh S, Herat S (2009) Bioremediation of contaminated sites: a low-cost nature's biotechnology for environmental clean up by versatile microbes, plants \& earthworms. In: Faerber T, Herzog J (eds) Solid waste management and environmental remediation. Nova Science Publishers Inc, New York (ISBN 978-1-60741-761-3)

Sonesson U, Bjorklund A, Carlsson M, Dalemo M (2000) Environmental and economic analysis of management systems for biodegradable waste. Resour Conserv Recycl 28:29-53

Sorek N, Yeats TH, Szemenyei H, Youngs H, Somerville CR (2014) The implications of lignocellulosic biomass chemical composition for the production of advanced biofuels. Bioscience (Oxford) 64:192-201. https://doi.org/10.1093/biosci/bit037

Sudharmaidevi CR, Thampatt KCM, Saifudeen N (2017) Rapid production of organic fertilizer from degradable waste by thermochemical processing. Int J Recycl Org Waste Agric 6:1-11. https://doi.org/10.1007/s40093-016-0147-1

Tláskal V, Voříšsová J, Baldrian P (2016) Bacterial succession on decomposing leaf litter exhibits a specific occurrence pattern of cellulolytic taxa and potential decomposers of fungal mycelia. FEMS Microbiol Ecol 92:fiw177. https://doi.org/10.1093/ femsec/fiw 177

Trivedi P, Delgado-Baquerizo M, Anderson IC, Singh BK (2016) Response of soil properties and microbial communities to agriculture: implications for primary productivity and soil health indicators. Front Plant Sci 7:990. https://doi.org/10.3389/ fpls.2016.00990

Urbanová M, Šnajdr J, Baldrian P (2015) Composition of fungal and bacterial communities in forest litter and soil is largely determined by dominant trees. Soil Biol Biochem 84:53-64. https://doi.org/10.1016/j.soilbio.2015.02.011 
Valverde ME, Hernandez-Perez T, Paredes-Lopez O (2015) Edible mushrooms: improving human health and promoting quality life. Int J Microbiol 2015:376387. https://doi. org/10.1155/2015/376387

Varma VS, Das S, Sastri CV, Kalamdhad AS (2017) Microbial degradation of lignocellulosic fractions during drum composting of mixed organic waste. Sustain Environ Res 27:265-272. https ://doi.org/10.1016/j.serj.2017.05.004

Venglovsky J, Sasakova N, Placha I (2009) Pathogens and antibiotic residues in animal manures and hygienic and ecological risks related to subsequent land application. Bioresour Technol 100:5386-5391. https://doi.org/10.1016/j.biortech.2009.03.068

Veselá M, Friedrich J (2009) Amino acid and soluble protein cocktail from waste keratin hydrolysed by a fungal keratinase of Paecilomyces marquandii. Biotechnol Bioprocess Eng 14:84-90. https://doi.org/10.1007/s12257-008-0083-7

Vigneswaran S, Kandasamy J, Johir MAH (2016) Sustainable operation of composting in solid waste management. Procedia Environ Sci 35:408415. https://doi.org/10.1016/j.proenv.2016.07.022

Villar I, Alves D, Garrido J, Mato S (2016) Evolution of microbial dynamics during the maturation phase of the composting of different types of waste. Waste Manag 54:83-92. https://doi. org/10.1016/j.wasman.2016.05.011

Vishan I, Sivaprakasam S, Kalamdhad A (2017) Isolation and identification of bacteria from rotary drum compost of water hyacinth. Int J Recycl Org Waste Agric 6:245-253. https://doi.org/10.1007/ s40093-017-0172-8

Voříšková J, Baldrian P (2013) Fungal community on decomposing leaf litter undergoes rapid successional changes. SME J 7:477-486. https://doi.org/10.1038/ismej.2012.116

Weber C, Farwick A, Benisch F, Brat D, Dietz H, Subtil T et al (2010) Trends and challenges in the microbial production of lignocellulosic bioalcohol fuels. Appl Microbiol Biotechnol 87:1303-1315. https://doi.org/10.1007/s00253-010-2707-Z

Wei T, Zhang P, Wang K, Ding R, Yang B, Nie J, Jia Z, Han Q (2015) Effects of wheat straw incorporation on the availability of soil nutrients and enzyme activities in semiarid areas. PLoS One 10:e0120994. https://doi.org/10.1371/journal.pone.0120994

Weiland P, Verstraete W, van Haandel A (2009) Biomass digestion to methane in agriculture: a successful pathway for the energy production and waste treatment worldwide. In: Soetaert W, Vandamme EJ (eds) Biofuels. Wiley, New Jersey, pp 171-196. https ://doi.org/10.1002/9780470754108.ch10

Yadav SK, Babu S, Yadav MK, Singh K, Yadav GS, Pal S (2013) A review of organic farming for sustainable agriculture in Northern India. Int J Agron. https://doi.org/10.1155/2013/718145

Yildirim N, Yildirim NC, Yildiz A (2015) Laccase enzyme activity during growth and fruiting of Pleurotus eryngii under solid state fermentation medium containing agricultural wastes. Int J Pure Appl Sci 1:64-71

Zeng Y, De Guardia A, Dabert P (2016) Improving composting as a post-treatment of anaerobic digestate. Bioresour Technol 201:293-303. https://doi.org/10.1016/j.biortech.2015.11.013

Zhang J, Zeng G, Chen Y et al (2013) Impact of Phanerochaete chrysosporium inoculation on indigenous bacterial communities during agricultural waste composting. Appl Microbiol Biotechnol 97:3159-3169. https://doi.org/10.1007/s00253-012-4124-y

Zhang Y, Geng W, Shen Y, Wang Y, Dai Y-C (2014) Edible mushroom cultivation for food security and rural development in China: bioinnovation, technological dissemination and marketing. Sustainability 6:2961-2973. https://doi.org/10.3390/su6052961

Zhang X, Sun N, Wu L, Xu M, Bingham IJ, Li Z (2016) Effects of enhancing soil organic carbon sequestration in the topsoil by fertilization on crop productivity and stability: evidence from long-term experiments with wheat-maize cropping systems in China. Sci Total Environ 562:247-259. https://doi.org/10.1016/j. scitotenv.2016.03.193

Zhen Z, Liu H, Wang N, Guo L, Meng J, Ding N, Wu G, Jiang G (2014) Effects of manure compost application on soil microbial community diversity and soil microenvironments in a temperate cropland in China. PLoS One 9:e108555. https://doi.org/10.1371/ journal.pone.0108555

Publisher's Note Springer Nature remains neutral with regard to jurisdictional claims in published maps and institutional affiliations. 